\title{
HAMOGLOBINURIA IN THE NEWBORN
}

\author{
BY \\ JEAN SMITH, M.D., M.R.C.P., \\ Medical Registrar, Infants' Hospital, London.
}

Hæmoglobinuria occurring at any age is an interesting study, but the dramatic character of its onset and its striking symptomatology in the newborn, combined with the additional information which more frequent post-mortem investigation affords, lend special interest to hæmoglobinuria in early infancy. The literature on this subject is almost entirely foreign, for, whereas several cases have been recorded from Germany, fiustria, France, Russia and America, the only English one which could be traced was that described by Feldman ${ }^{11}$ in 1927. The rarity of the condition in England and the knowledge gained from the pathological investigations give interest to the following case, published by kind permission of Dr. Eric Pritchard.

A.B., a female infant, aged one month, was admitted to the Infants' Hospital on January 8th, 1930. She was born on December 5th, 1929, of young parents. The father was said to be healthy and the mother, apart from a mild degree of albuminuria during the last months of pregnar;cy, was also healthy. The birth weight was $5_{2}^{1} \mathrm{lb}$. and except for some slight feeding difficulties resulting from the necessity for supplementing the breast milk, the child appeared a normal, though perhaps not a very lusty, infant. On the twenty-first day, however, a rose-coloured morbilliform rash appeared on the chest and was especially profuse in the axillæ; the limbs, neck and face were not involved. No constitutional disturbance or pyrexia accompanied this rash which disappeared in three days. On January 6th, at 6 a.m., that is, when the child was thirty-two days old, the nurse noticed that the child became 'black all over.' It continued to take its feeds well and there was still no pyrexia. The umbilicus was healthy. The stools and urine remained normal until the morning of January 8th, when the motions became dark green ard the urine a pinkish browr. On further enquiry, it was found that there had been very slight bleeding from the anus during the second week due to the passage of hard constipated motions, but with the administration of laxatives this bleeding had ceased.

On admission, the child was a small but not much wasted infant weighing $4 \frac{1}{2} \mathrm{lb}$. It was extremely lethargic and only took small feeds and those with difficulty. The skin was dry, lax and parchment-like and of an uniform dusky blue colour; the sclerotics were jaundiced. There were areas of desquamating skin on the chest, abdomen and hands, but the umbilicus was dry and there were no raw, ulcerated areas to be seen. The stools were loose, dark green and slimy, and the urine turbid and dark red-brown in colour. Very little urine was passed although no exact measurement was possible. The temperature on admission was $101 \cdot 2^{\circ}$ but it fell quickly and remained subnormal throughout, on one cceasion reaching $92 \cdot 8^{\circ}$. The pulse was 140 and extremely feeble: the "shallow respirations varied from 25 to 60 per minute. The liver was felt one finger's breadth below the costal margin but the spleen was not palpable. Further clinical examination of the chest and abdomen revealed no other abnormalities. The day after admission, the discolouration of the skin became distinctly less marked, but the character of the stools and the urine remained unchanged. On January 11th, the child became increasingly drowsy and died.

Investigations.- - On pricking the heel, the blood which exuded was brown, not red, in colour and after centrifuging, the serum was an olive-coloured, translucent fluid while the corpuscles formed a dark rusty brown precipitate at the bottom of the tube. Spectroscopic examination 
of the serum revealed the presence of oxyhæmoglobin bands only. The indirect Van den Bergh test was slightly positive, and the fragility of the red cells slightly increased, partial hæmolysis taking place in 0.5 per cent. and total hæmolysis in 0.48 per cent. saline. The Wassermann reaction was negative in the mother, but the test on the infant's blood was not satisfactory and unfortunately it could not be repeated. The urine was faintly acid and was shown spectroscopically to contain methæmoglobin. The guaiacum test was positive and there was much albumin present, but no blood cells or casts were seen. The fæces gave a faint positive test for blood, but this may have been due to urinary contamination.

Post-mortem examination.- The body was that of a slightly wasted small infant. The skin was shrunken and of a paler dusky hue than that observed during life. The intercostal and other striped muscles were extremely pale. The pericardium contained about $1.5 \mathrm{c.cm}$. of clear brownish yellow fluid. The heart-muscle was pale and flabby and the foramen ovale patent, but the valves and the great vessels were noimal and ductus arteriosus obliterated. A few minute petechial hæmorrhages were present on the costal surfaces of the lungs which otherwise appeared normal. The liver (145 grm.) was smooth and firm and showed some slight yellow staining. The stomach was somewhat dilated and the mucous membranc of the intestine was injected. The spleen was firm and a dark brown-red in colour but was not unduly large. The kidneys were slightly enlarged the increase in size being due to the cortex which was wider than normal and of a pale brown colour, while the pyramids were dirk brown and showed striations of a still deeper shade of brown in the direction of the tubules. On treating pieces of the liver, spleen and kidney with potassium ferrecyanide and hydrochloric acid, the liver and spleen changed to a dense prussian blue colour while the kidreys showed a very pretty distinction between the cortex and the medulla. The cortex gave the prussian blue reaction while the pyramids retained their red-brown striated appearance (Fig. 1).

Microscopic examination.-Sections of the kidney, liver and spleen were stained for hæmosiderin by Abbott's method and then counter-stained with hæmatoxylin and eosin. The renal glomeruli in many places showed dilatation of their capsules and some of the adjacent tubules contained an eosin-staining hæmoglobin precipitate. The cells of the convoluted tubules contained considerable quantities of hæmosiderin. The medulla, as was expected from the microscopic section, showed no hæmosiderin, but many of Henle's tubules were considerably dilated and were filled with an amorphous brown material, which formed the basis of the striations seen in the pyramids by the naked eye and represented what were described by the earlier writers as 'hæmoglobin infarcts.' The liver and the spleen showed large quantities of hæmosiderin, granules being present in the Kupffer cells, the liver cells themselves, and in the cells of the splenic pulp.

Historical.-Although von Winckel's ${ }^{41}$ name is associated with hæmoglobinuria in the newborn, a careful reading of the literature will show that he was not the first to describe the condition.

As early as 1873, that is six years before von Winckel's paper appeared, Parrot ${ }^{28}$ published two cases of what he termed 'tubulhématie rénale', and in the same year Charrin ${ }^{6}$ and Laroyenne ${ }^{23}$ described thirteen cases of 'maladie bronzée hématurique' which were almost certainly cases of hæmoglobinuria rather than hæmaturia. Indeed, Parrot himself says that no blood cells were found in the urine. Nevertheless, it is probable that an even earlier descrijtion was given by Otto Pollak ${ }^{29}$ in 1871 , although he was labouring under the misapprehension that he was describing hæmaturia from thrombosis of the renal veins. He described, however, what he considered to be a new and singularly fatal symptom-complex occurring in newloorn children affected with enteritis and associated with a peculiar discolouration of the skin, chocolate ccloured urine (from which he prepared hæmatin crystals), and striking naked-eye changes in the renal medulla; and these details conform so closely to those of other writers

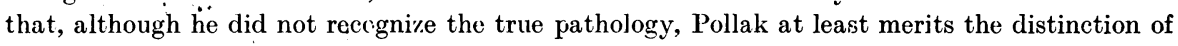
having first recorded observations on the subject. The next rame to appear in connection with this subject was that of Bigelow ${ }^{4}$, who in 1875 published a paper on 'Septic Poisoning : Discoloured Skin : Diphtheria : Hæmaturia,' and although von Reuss ${ }^{32}$ acquiesces in this author's statcment that it was hæmaturia, it is clear on reading the paper that it was not hæmaturia ; for Bigelow himself says that in some cases there was 'a coagulum in the bladder extending up 
FIG. 1.-Kidney stained with potassium ferrocyanide and hydrochloric acid. Showing free iron in the cortex. The collection of pigment at the apices of the pyramids is also seen.

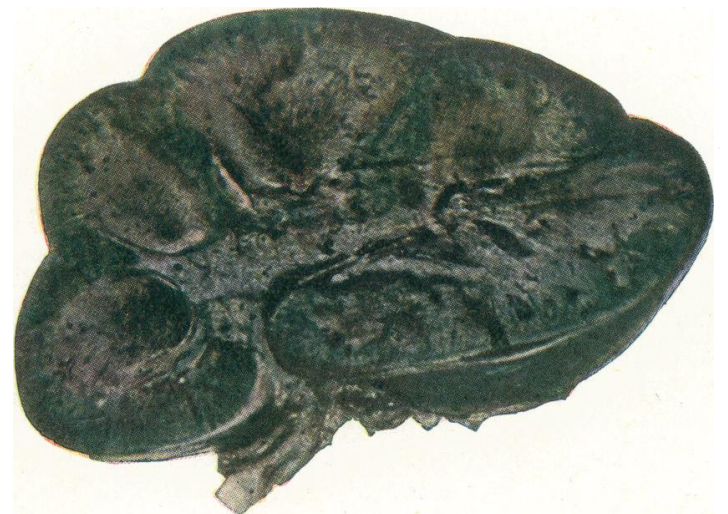


the ureters and filling the kidneys, the tubes of which were filled with highly solid materials of the blood which had penetrated into their interior. This material was amorphous and in no case was a well defined blood corpuscle found inside the tube.' Von Winckel's claim to priority rests on his discovery that the colouring matter in the urine was hæmoglobin and not blood. Following von Winckel's paper reports of isolated cases appeared by Sandner ${ }^{34}$, Strelitz ${ }^{37}$, Kamen $^{21}$ and Finkelstein ${ }^{13}$ and two epidemics were recorded by Wolcynski ${ }^{42}$ and $\mathrm{Ljwow}^{24}$. Epstein $^{10}$, Ritter ${ }^{33}$ and Francioni ${ }^{15}$ added further records, so that in 1910, Brandenberg ${ }^{5}$ was able to collect 50 cases in the literature. Since then papers have appeared by Weihe ${ }^{39}$ and Bass $^{3}$.

Etiology.-The large number of conditions and the variety of microorganisms with which hæmoglobinuria has been associated are sufficient proof of the uncertainty of our knowledge of its causation at the present time. Diphtheria (Bigelow ${ }^{4}$ ), B. coli (Wolcynski), streptococci (Finkelstein ${ }^{13}$, Strelitz ${ }^{37}$, Anders and Stern ${ }^{1}$ ), pseudo-diphtheritic bacilli (Francioni ${ }^{15}$ ), pneumonia (Devenspeck ${ }^{9}$, Comby ${ }^{8}$, Meyer ${ }^{25}$ ), amœbiasis (Fiessinger and Partutier ${ }^{12}$ ), scarlet fever (Miller ${ }^{26}$, Gunther ${ }^{17}$ and Heubner $\left.{ }^{18}\right)$, tetanus (Wagner $\left.{ }^{38}\right)$, erysipelas (Langer ${ }^{22}$ ), malaria (Genoese $\left.{ }^{16}\right)$, typhus (Immermann ${ }^{19}$ ), umbilical sepsis (Parrot ${ }^{28}$ ), thrush and erysipelas (Parrot), and varicella (Kaiser and Bradford ${ }^{20}$ ) have all been held responsible for hæmoglobinuria; nor can the exact relationship between malaria and blackwater fever and syphilis and paroxysmal hæmoglobinuria be considered established. Bigelow's report of the epidemic which occurred in the Boston Lying-in Hospital between September and December, 1873, shows a very striking association with infection. The chief symptoms were:--sore mouths; diphtheritic membranes in the mouth, larynx and osophagus; conjunctival discharge; puriform softening of the contents of the umbilical cord in one case ; peritonitis in one case and acute atrophy of the liver in another. Bigelow seems to have thought that the material in the renal tubules consisted of spores and that these spores were the same as those found in the diphtheritic membranes elsewhere. It must be remembered that the diphtheria bacillus was not discovered by Klebs until 1883, nor its pathogenic and cultural characteristics by Loeffler until 1884 .

The epidemic described by Ljwow ${ }^{24}$ confirms this conception of the relationship of sepsis and hæmoglobinuria in the newborn. Concurrent with the epidemic of hæmoglobinuria in the newborn infants, there was an outbreak of puerperal sepsis among the mothers of the affected infants. Other points in favour of an infective origin in these cases are the leucocytosis (even allowing for the high white blood count which is found in the newborn), and the skin rashes which have been described in those cases in which a micro-organism was not sought or else not discovered. Burnett has expressed the view that while in older children B. coli may cause pyelitis, Henoch's purpura or lichen urticatus, its invasion of the newborn causes Winckel's disease. It seems both unnecessary and misleading to limit the responsibility to the $\mathrm{B}$. coli, and it is probably more correct to say that any pathogenic organism, providing the infection be sufficiently virulent, can cause hæmoglobinuria in the newborn.

Nomenclature.-Von Winckel described this condition as 'cyanosis afebrilis ictera cum hæmoglobinuria,' but not all cases are afebrile, although admittedly pyrexia is never a striking feature. Still, even if it were absent, 
severe infections in the newborn are frequently afebrile. Nor is cyanosis the best description of the discolouration of the skin which more closely resembles the slate-like colour seen in argyria with an underlying icteroid basis. It is suggested therefore that 'infective hæmoglobinuria of the newborn' is a more comprehensive and satisfactory designation

Pathological Physiology.-Three points of interest require discussion here.

ChaNges IN The BLOOD SERUM AND FRagility OF THE RED CELls.-Recent work on the various types of hæmoglobinuria suggests that they are more closely allied than was previously thought. The Donath-Landsteiner reaction which was originally regarded as a specific test for paroxysmal hæmoglobinuria has recently been shewn by Kaiser and Bradford to be positive in hæmoglobinuria associated with chickenpox. Repeated tests during the height of the attack were positive, while during convalescence negative results were invariably obtained. Moreover, Puris ${ }^{31}$ regards it open to reasonable doubt whether the positive Wassermann reaction obtained in patients suffering from paroxysmal hæmoglobinuria is really indicative of syphilis, or merely due to a change in the blood serum. It is well known that a positive reaction may be obtained in streptococcal infections, acute exanthemata, pneumonia and malaria and other diseases. On the other hand, Foix and Salin ${ }^{14}$ believe that in paroxysmal hæmoglobinuria in addition to the changes in the blood serum, a special fragility of the red cells must be assumed. This was confirmed by Puris in a case of paroxysmal hæmoglobinuria, and was also true of the case of hæmoglobinuria of the newborn recorded here. At the same time it may be recalled that increased fragility of the red cells has been recorded in cases of streptococcal pyæmia. Is it not possible that there may be a connection between (1) the positive complement fixation test which has been found in paroxysmal hæmoglobinuria, streptococcal infections, the acute exanthemata and pneumonia; (2) the increased fragility of the red cells in paroxysmal hæmoglobinuria, streptococcal infections and the case of hæmoglobinuria of the newborn here described; and (3) the hæmoglobinuria?

Christophers and Bentley ${ }^{7}$ found an autolysin in the serum of blackwater fever patients which autolysin was apparently formed as a result of destruction of the red cells in malaria, and this on attacking the remaining red cells gave rise to blackwater fever. It seems possible that infection in the newborn may give rise to a similar train of events. It is much regretted that the very small quantity of blood obtained from this patient did not permit of testing its hæmolytic action on cells derived from other human beings.

The EXCRETION OF HAMOgLOBIN.-Qn looking through the literature, the similarity of the changes observed to those seen in experimental hæmoglobinuria in rabbits (Muir ${ }^{27}$ ), in blackwater fever (Yorke and Nauss ${ }^{43}$ ) and in cases of transfusion of incompatible blood (Baker and Dodds ${ }^{2}$ ) is striking. Muir has demonstrated experimentally that when there is hæmoglobinæmia for some time without hæmoglobinuria, the hæmoglobin is split up in the cells of the convoluted tubules of the kidney and the hæmosiderin is retained within them. In the case recorded, if the discolouration of the skin be taken as evidence of hæmoglobinæmia, then this had existed for at least forty-eight 
hours before the hæmoglobinuria became manifest. In Fig. 2 the hæmosiderin granules are seen within the cells of the convoluted tubules. The presence of granules in the renal tubules was described by Parrot and many others of the earlier writers. That these infarcts may constitute a grave danger is emphasized by both Baker and Dodds ${ }^{2}$, and Yorke and Nauss ${ }^{43}$. It is interesting to recall that Parrot considered the convulsions observed in one of his patients to be due to uræmia. Yorke and Nauss writing on the mechanism of the production of the suppression of urine in blackwater fever, state that under certain conditions the mere passage of hæmoglobin through the kidneys of a healthy animal is sufficient to cause suppression of urine

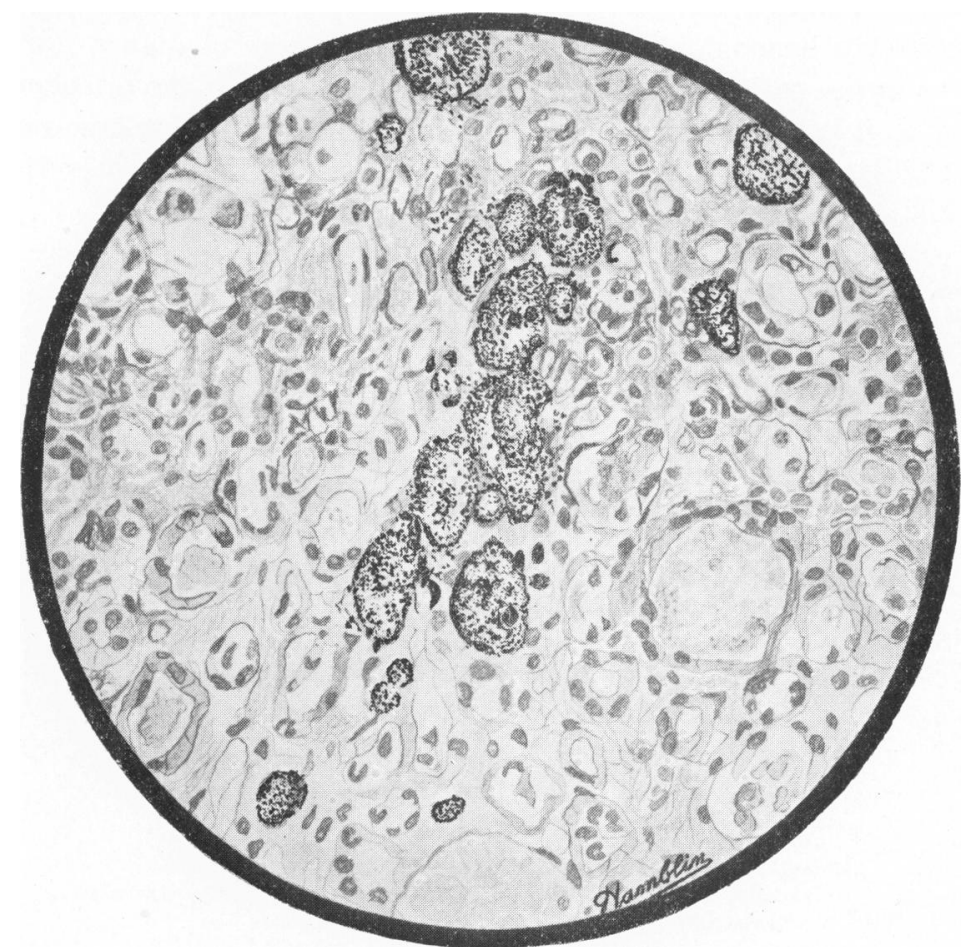

Fic. 2.- Section through the pyramids. Masses of amorphous pigment are seen to fill the dilated tubules.

owing to occlusion of the renal tubules by plugs of granular material derived from the hæmoglobin. They add that this process is greatly facilitated by a lowering of blood pressure and the consequent diminished secretion of water by the Malpighian capsules. When the blood volume is kept up by the injection of saline and feeding the animal on moist foods, a large amount of hæmoglobin can be injected without any tendency to suppression of urine. Baker and Dodds found that if rabbits were kept on an ordinary diet so that they passed alkaline urine, they were unaffected by injections of hæmoglobin, whereas if the urine were kept acid by means of a suitable diet, intra-renal obstruction could be produced. They concluded that the hæmoglobin is 
excreted in the glomerular transudate, and that after concentration in the tubules the acidity and the salt concentration increase, with the result that the pigment is precipitated probably in the form of hæmatin. Various names have been given to the iron-free pigment in the tubules. Originally called ' hæmoglobin infarcts,' they were later described as 'hæmofuscin' and still later, hæmatin. As Muir says, however, the term 'hæmofuscin' has been applied to so many different substances that it should either be defined or discontinued. Whatever their composition, it is evident that the degree of renal obstruction they may cause may be an important factor in determining the issue for the patient.

HæMOGLOBIN æMIA AND HжMOgLOBINURIA.-Hæmoglobinuria postulates the presence of a hæmoglobinæmia, although it may be of only a few hours duration, as in the paroxysmal type. On the other hand, if the discolouration of the skin be taken as a criterion, then it is possible, as in one case reported

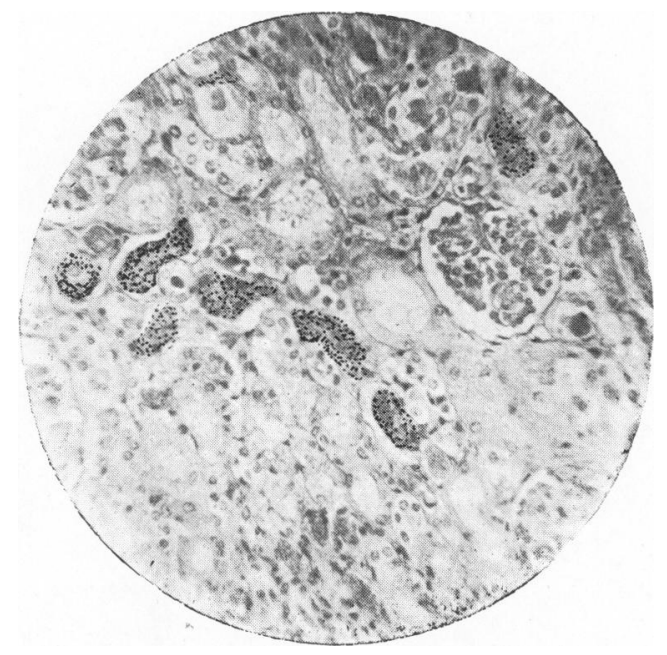

FIt: 3.--A micro-photograph of a section through the cortex. Several dilated tubules and a glomerular capsule are shown. The cells of many of the convoluted tubules are heavily loaded with hæmosiderin granules.

by Bigelow, for hæmoglobinæmia of a fairly severe degree to be present for seven days before hæmoglobinuria appears. Icterus is an earlier symptom and is also present in less severe cases, and may be taken as evidence of hæmolysis of a greater extent than the liver can deal with. The chief factor influencing the appearance of hæmoglobin in the urine must be the extent of hæmolysis which has occurred, since there is a definite renal threshold for hæmoglobin. Ponfick ${ }^{30}$ and Stadelmann ${ }^{36}$ have shown that hæmoglobinuria does not occur until the amount of hæmoglobin reaches one-sixtieth of the total hæmoglobin of the body, and that a destruction of red cells may take place almost to the equivalent of this content without the appearance of hæmoglobinuria. Sellards and Minot $^{35}$ found that $25 \mathrm{c.cm}$. of packed human red blood cells could be injected into normal human beings without symptoms, 
but that greater amounts caused hæmoglobinuria. Moreover, the renal threshold was much lower in individuals whose serum contained the free hæmoglobin resulting from rapid blood destruction.

Symptomatology.-The most striking and often the first symptom to appear is the discolouration of the skin which appears usually during the first week of life. In the Dresden epidemic the child usually fell ill on the fourth day; in the Boston outbreak the onset was rather later, often at the beginning of the second week. The infant described by Francioni was twentysix days old when the first symptoms appeared, and the child recorded here was thirty-two days old. The colour of the skin varies from a faint dusky hue to a dark slate colour resembling argyria with an underlying icteroid tint, which colour shows most clearly in the sclerotics. The discolouration is generalized and is just as pronounced on the trunk as on the face and extremities, and it persists to a less marked degree after death. The infants are extremely lethargic and take their feeds very badly. The respirations are feeble and the temperature often, though not without exception, subnormal. The stools are loose and dark green, resembling meconium, and the urine is of a deep brown colour. The liver is usually enlarged but the spleen may or may not be palpable. The urine is acid. The depth of the colour depends on the amount of hæmoglobin which further varies with the degree of hæmolysis. Casts may be found and spectroscopically, methæmoglobin is seen to be present.

Prognosis.-The prognosis is extremely grave, recovery occurring in only a few instances. Only four infants out of the twenty-three attacked in the Dresden epidemic, and two out of ten in the Boston outbreak, survived. The outlook for older children suffering from hæmoglobinuria of infective origin is very different, complete recovery being the rule. In infants death usually takes place two or three days after the first symptom has been noticed, but it may occur in a few hours or it may be delayed for several days.

Diagnosis.--The discolouration of the skin may suggest a diagnosis of congenital heart disease, but it is generalized and is as marked on the body as elsewhere, which is not the case in congenital heart disease. Methæmoglobinæmia and sulphæmoglobinæmia may resemble this condition superficially, but the diagnosis can be established by the syrupy consistence of the blood on pricking the heel, the brown colour of the serum and the rusty-coloured precipitate of the red corpuscles, which when examined in a film preparation are seen to be of various sizes and shapes and many almost devoid of hæmoglobin-the so-called shadow corpuscles.

Treatment.-It is questionable whether in the face of such an overwhelming catastrophe as must have taken place in these cases any form of therapy would be of avail, but two lines of treatment may be recommended.

(1) If the cause of the condition and the infecting organism be known, then specific treatment in the form of intravenous serum may be tried.

(2) Attempts to keep up the blood volume and to prevent blocking of the renal tubules by means of the administration of alkaline diuretics have a rational basis. 


\section{Conclusions.}

(1) A case of infective hæmoglobinuria in the newborn is described together with pathological findings.

(2) The ætiology of this condition is discussed and 'infective hæmoglobinuria of the newborn' is suggested as a suitable designation.

(3) Experimental work on the excretion of hæmoglobin in rabbits and the deposition of hæmosiderin in the cells of the convoluted tubules is confirmed.

(4) The pathology of renal obstruction in this and other forms of hæmoglobinuria is surveyed and suggestions for treatment made.

(5) Further work on the Wassermann reaction and the fragility in this and other forms of infection in the newborn would be helpful.

\section{REFERENCES.}

1. Anders, H. E., \& Stern, G., Arch. f. Kinderh., Stuttgart, 1922, LXXI, 101.

2. Baker, S. L., \& Dodds, E. C., Brit. J. Exper. Path., Lond., 1925, VI, 247.

3. Bass, M. H., Arch, Pediat., N.Y., 1918, XXXV, 84.

4. Bigelow, W. S., Boston Med. and Surg. J., Boston, 1875, XCII, 277.

5. Brandenberg, F., Arch. f. Kinderh., Stuttgart, 1911, LV, 271.

6. Charrin, S., Thèse de Paris, Paris, 1873.

7. Christophers \& Bentley, (quoted by Muir, loc. cit., 422).

8. Comby, J., Arch. de méd. d'enf., Paris, 1926, XXIX, 532.

9. Doevenspeck, quoted by Gunther, loc. cit.

10. Epstein, quoted by Gunther, loc. cit.

11. Feldman, W. H., Brit. J. Child. Dis., Lond., 1927, XXIV, 113.

12. Fiessinger \& Parturier, G., Bull. et mèm. Soc. mèd. d'hôp. de Paris, Paris, 1926, I, 153.

13. Finkelstein, H., Berlin klin. Wchnschr, Berlin, 1895, XXXII, 436.

14. Foix, C., \& Salin, H., Arch. de méd. exper. et d'anat. path, Paris, 1912, XXIV, 305.

15. Francioni, C., Monatschr. f. Kinderh., Leipzig, 1909, VII, 717.

16. Genoese, G., Pediatria, Naples, 1928, XXXVI, 465.

17. Gunther, B., Deutsch. med. Wchnschr., Leipzig, 1923, XLIX, 219.

18. Heubner, quoted by Gunther, loc. cit.

19. Immermann, quoted by Gunther, loc. cit.

20. Kaiser, A. D., \& Bradford, W. L., Arch. Ped., N.Y., 1929, XLVI, 571.

21. Kamen, L., Beitr. z. path. Anat. u. z. allg. Path., Jena, 1893, XIV, 132.

22. Langer, quoted by Gunther, loc. cit.

23. Laroyenne, Assoc. franc. pour l'buance. de sc. Compt. Rend., Paris, 1873.

24. Ljwow, I. M., Med. Obosr., Moscow, 1893, XI, 142.

25. Meyer, G. A., quoted by Gunther, loc. cit.

26. Miller, J. W., Berlin klin. Wchnschr., Berlin, 1912, XLIX, 1921.

27. Muir, R., Textbook of Pathology, Lond., 1929, 47.

28. Parrot, J., Arch. de phys. norm. et path., Paris, 1873, V, 512.

29. Pollak, O., Wien. med. Presse, Vienna, 1871, XVIII, 457.

30. Pcnfick, E., quoter by Puris, loc, cit.

31. Puris, A. M., Am. J. Dis. Child., C'hicago, 1929, XXXVII, 1027.

32. v. Reuss, A. R., Diseases of the Newborn, Eng. trans., 1921, 467.

33. Ritter, quoted by v. Reuss, loc. cit.

34. Sandner, C., Münch. med. Wochnschr., München, 1886, XXXIII, 421.

35. Sellards, A. W., \& Minot, G. R., J. Med. Res., Boston, 1916, XXXIV, 469.

36. Stadelman, E., Arch.f. exper. Path. u. Pharmakoi, Leipzig, 1890, XXVII, 93.

37. Strelitz, Arch.f. Kinderh., Stuttgart, 1890, VIII, 11.

38. Wagner, quoted by Gunther, loc. cit.

39. Weihe, F., Ztschr.f. Kinderh., Berlin, 1918, XVIII, 319.

40. Weil, P. E., \& Chevalier, P., Compt. Rend. Soc. de Biol., Paris, 1913, LXXV, 475.

41. v. Winckel, Deutsch. med. Wchnschr., Leipzig, 1879, V. 303.

42. Wolcynski, Intern. lilin. Rundschau, Vienna, 1873, 960.

43. Yorke, W., \& Nauss, R. W., Ann. Trop. Metl. \& Parisitol., Liverpool, 1911, V, 287, 